\title{
Abigeatus - mājlopu zādzība jeb aizdzīšana - kā noziedzīgs nodarījums pret îpašumu romiešu tiesībās
}

\author{
Dr. iur. Allars Apsītis \\ ORCID: 0000-0002-8363-6981 \\ Rìgas Stradiña universitāte, Latvija \\ jf@rsu.lv \\ Dr. habil. iur. Osvalds Joksts \\ Rìgas Stradina universitāte, Latvija \\ jf@rsu.lv
}

\section{Kopsavilkums}

Rakstā atspoguḷoti atsevišşi rezultāti no autoru realizētās romiešu tiesību pirmavotu izpētes saistībā ar tajos atrodamo informāciju par noziedzīgiem nodarījumiem pret īpašumu, kas mūsdienu Latvijā kriminalizēti Krimināllikuma 175. pantā "Zādzība", 176. pantā "Laupīšana" un 179. pantā "Piesavināšanās". Apskatīta un analizēta tiesiskā reglamentācija attiecībā uz abigeatus - mājlopu zādzību jeb aizdzī̌̌nu, kas tika uzskatìta par bīstamāku un smagāku nodarījumu nekā parasta zādzība (lat. furtum) un tāpēc bargāk sodīta. Aplūkoti arī minētā noziedzīgā nodarījuma kvalifikācijas un sodīšanas politikas legālie kritēriji romiešu tiesībās. Saskaṇā ar autoru informāciju Latvijas pētnieki šo tematiku visai maz apskatījuši, un pētỉjums varētu dot zināmu ieguldījumu nacionālās tiesību zinātnes attīstībā, īpaši jautājumā par romiešu tiesību principu ietekmi uz Latvijas Republikas normatīvajos aktos ietvertajiem mūsdienu tiesību institūtiem.

Atslēgvārdi: abigeatus, mājlopu aizdzišana, mājlopu zādzība, romiešu tiesības.

\section{levads}

Pētỉjums tapis kā atseviškss elements no autoru realizētās romiešu tiesību pirmavotu izpētes attiecībā uz tajos atrodamo informāciju par noziedzīgiem nodarỉjumiem pret ìpašumu - svešas kustamas mantas nolaupī̌sanu un svešas mantas prettiesisku iegūšanu vai izšḳērdēšanu, kas mūsdienu Latvijā kriminalizētas Krimināllikuma 175. pantā "Zādzība”, 176. pantā "Laupīšana", 179. pantā "Piesavināšanās" [7]. 
Tā kā autoru veiktā pētỉjuma rezultāti par romiešu zādzības (lat. furtum) koncepciju jau tikuši publicēti, ${ }^{1}$ šoreiz lasītājiem tiek piedāvāta informācija par abigeatus (lat.) mājlopu zādzību jeb aizdzīšanu, kas, n̦emot vērā noziedzīgā nodarījuma priekšmeta īpašo ekonomisko nozīmību seno romiešu tautsaimniecībā un noziedzịgā nodarījuma pastrādāšanai bieži lietoto paṇēmienu paaugstināto sabiedrisko bīstamību (mūsdienu Latvijas apstākḷ̆os līdzīgu darbību gadījumā citu starpā varētu tikt piemērots Krimināllikuma 21. pants "Organizēta grupa" un 224. pants "Bandītisms" [7]), tika izdalīta kā atsevišķs antīkā noziedzīgā nodarījuma paveids.

Saskaṇā ar autoru rīcībā esošo informāciju Latvijas pētnieki minēto tematiku ir visai maz apskatījuši. Tādēl pētījums varētu dot zināmu ieguldījumu nacionālās tiesību zinātnes attīstībā - arī jautājumā par romiešu juridisko principu ietekmi uz moderno, īpaši Latvijas Republikas tiesībās ietverto, tiesisko institūtu attīstību.

Pētījuma gaitā veikta tā sauktās Justiniāna kodifikācijas (pazīstama arī ar nosaukumu "Corpus Iuris Civilis") daḷās "Codex Iustinianus" ("Justiniāna kodekss", 534. AD) [4], "Digesta seu Pandectae" ("Sakārtojums vai sakopojums", 533. AD) [5] un "Institutiones sive elementa" ("Institūcijas jeb elementi", 533. AD) [6] ietvertās informācijas izpēte un analīze, izmantojot induktīvo, deduktīvo un salīdzinošo metodi.

\section{Rezultāti}

Abigeatus (lat.) - mājlopu zādzība jeb aizdzī̌sana ${ }^{2}$ no stallı ${ }^{3}$ vai ganībām $[2,338]$ (arī meža ganībām) un ganāmpulkiem ${ }^{4}$ tika uzskatīta par bīstamāku un smagāku pārkāpumu nekā vienkārša, parasta zādzība (lat. furtum) ${ }^{5}$ un attiecīgi smagāk sodìta. ${ }^{6}$

Savukārt noziedzīgā nodarỉjuma subjekts - mājlopu zaglis / aizdzinējs (lat. abigeus, arī abactor) [2, 338] - kvalificējas kā zināma veida pārkāpējs profesionālis. Saskaņā ar romiešu juristu viedokli pie mājlopu zag̣̦iem / aizdzinējiem îsteni bija piederoši tikai tie, "kuri liellopus no ganībām vai ganāmpulkiem atš̌kir un kaut kādā noteiktā veidā nolaupa" (lat. qui pecora ex pascuis vel ex armentis subtrahunt et quodammodo depraedantur) "un lopu zagšanas / aizdzǐšanas nodarbi gluži kā mākslu / arodu piekopj” (lat. et abigendi studium quasi artem exercent), "zirgus no ganāmpulkiem vai govis / vēršus no bariem projām aizvedot" (lat. equos de gregibus vel boves de armentis abducentes; D 47.14.1.1.) [5, 838].

1 Sk. Apsītis, A., Joksts, O. 2013. Noziedzīgs nodarījums zādzība ( furtum) romiešu tiesību kontekstā. Administratīvā un Kriminālā Justīcija. 1(62), 7-14.

2 Abigere (lat.) - aizdzīt, aizvest prom. (Autori izsaka pieṇēmumu, ka šeit varētu būt meklējami pirmsākumi mūsdienu profesionāḷ žargonā sastopamajai verbālajai konstrukcijai "automašīnastransportlīdzekḷa aizdzīšana”. Virspusēji raugoties, tas, protams, uzskatāms par pārāk tiešu tulkojumu -pārcēlumu no krievu valodas, tomēr minētā apzīmējuma izcelsme būtu dziḷākas izpētes vērta.)

${ }^{3}$ Sk. D 47.14.3.1.

4 Sk. D 47.14.1.1., D 47.14.3. pr., D 47.14.3.1.

5 Sk. D 47.14.1.1.

${ }^{6}$ Sk. D 47.14.1. pr., D 47.14.1.3., D 47.14.3.1., D 47.14.2. 
Allars Apsītis, Osvalds Joksts. Abigeatus - mājlopu zādzība jeb aizdzīšana -

kā noziedzīgs nodarījums pret ìpašumu romiešu tiesībās

Turklāt, lai sauktos par profesionālu mājlopu zagli, pietika tikai ar viena vienīga zirga vai liellopa aizvešanu - "zirgu, vērsi / govi pat vienu aizdzenot, mājlopu zādzības / aizdzīšanas noziegumu pastrādā" (lat. equum bovem vel unum abigeatus crimen facere).

Attiecībā uz romiešu ieskatā ekonomiski mazāk nozīmīgiem mājdzīvniekiem pastāvēja nedaudz pielaidīgāka attieksme. Viss bija atkarīgs no aizdzìto dzīvnieku skaita. Tā, ja kādi l̦aundari aizdzina desmit (vai vairāk) aitas (lat. decem oves), to uzskatīja par ganāmpulku (lat. gregem esse putaverunt) un vaininiekus atzina par tādiem, kas ir mājlopu zādzību / aizdzīšanu pastrādājuši (lat. abigeum faciunt). Savukārt, ja aizdzīto aitu skaits izrādījās mazāks par desmit, vainīgie bija pastrādājuši parastu zādzību (lat. furem) un kā mājlopu aizdzinēji nekvalificējās. Cūku zagḷiem šāds maǵiskais skaitlis bija četri "cūkas pat piecas vai četras aizdzitas (lat. porcos etiam quinque vel quattuor abactos)" (D 47.14.3. pr.) [5, 838].

Ja nācās saskarties ar recidīvistiem - tiem, "kuri ḷoti bieži / atkārtoti [lopus] zog / aizdzen ..” (lat. qui saepius abegerunt ..), mājlopu zādzība jeb aizdzīšana tika kvalificēta jebkurā gadījumā, lai kāds būtu aizvesto dzīvnieku veids vai skaits, - kaut arī l̦aundari vienmēr censtos aizvest tikai vienu vai otru no mäjlopiem (lat. unum vel alterum pecus subripuerint), vinuus vienalga atzìtu par ìsteniem minētā nodarïjuma subjektiem - "tomēr lopu zag̣̦i / aizdzinēji ir” (lat. tamen abigei sunt) (D 47.14.3.2.) [5, 838].

Par mājlopu zādzību jeb aizdzī̌sanu neatzina bez uzraudzības atstātu vai noklīdušu mājdzìnnieku nelikumīgu piesavināšanu - ".. ja kāds vērsi noklīdušu vai zirgus vienatnē pamestus būtu projām aizvedis" (lat. .. si quis bovem aberrantem vel equos in solitudine relictos abduxerit), "[viñ̌s] nav mājlopu zaglis / aizdzinējs" (lat. non est abigeus), "bet [ir] drīzāk [parasts] zaglis" (lat. sed fur potius) (D 47.14.1.1.) [5, 838].

Tā kā mājlopu zādzība / aizdzī̌sana (lat. abigeatus) romiešu ieskatā bija smagāks nelikumīgs nodarījums nekā parasta zādzība (lat. furtum), tad arī piemērojamie sodi bija visai bargi. Teritorijās, kur mājlopu aizdzīšanas netikums bija īpaši izplatìts un acīmredzot radīja izteikti jūtamus zaudējumus vietējai ekonomikai, kā arī sagādāja pastiprinātas problēmas ar sabiedriskās kārtības nodrošināšanu, mājlopu aizdzinējiem piemēroja nāvessodu: "Par mājlopu zag̣̣u / aizdzinēju sodīšanu šādi dievišḳais Hadriāns ${ }^{7}$ Bētikas ${ }^{8}$ konsīlijam [savā reskriptā] ir atbildējis" (lat. de abigeis puniendis ita divus Hadrianus consilio Baeticae rescripsit): "Mājlopu zag̣̣i / aizdzinēji ar vislielāko bardzību sodīti tiek" (lat. abigei cum durissime puniuntur), "[tos] ar zobenu notiesāt parasts" (lat. ad gladium damnari solent). "Sodīti tiek tomēr ar vislielāko bardzību ne visur" (lat. puniuntur autem durissime non ubique), "bet [tikai tur], kur biežāk [nekā citur] ir šāda veida l̦auni nodarījumi / l̦aundarības [izplatīi / izplatītas]" (lat. sed ubi frequentius est id genus maleficii)" (D 47.14.1. pr.) [5, 837]. “.. Hadriāns .. sodu [no] zobena noteicis” (lat. .. Hadrianus .. peonam .. gladii praestituerit) (D 47.14.1.3.) [5, 838].

\footnotetext{
7 Hadriāns (latviski saukts arī Adriāns; lat. Publius Aelius Hadrianus Augustus; 76.-138. AD) - Romas imperators no 117. lïdz 138. AD.

${ }^{8}$ Bētika (lat. Baetica) - Romas Impērijas province, kas atradās mūsdienu Spānijas dienvidu daḷā.
} 
Allars Apsītis, Osvalds Joksts. Abigeatus - mājlopu zādzība jeb aizdzīšana -

kā noziedzīgs nodarījums pret īpašumu romiešu tiesībās

Tāpat visai mežonīgs nāvessods - saplosīšana arēnā - mājlopu zagḷiem / aizdzinējiem draudēja gadījumos, kad dzīvnieki tika nolaupīti, izmantojot brunotu vardarbību: "Protams, [tie], kuri ar zobenu aizved / nolaupa" (lat. sane qui cum gladio abigunt), "nav netaisnīgi zvēriem / bestijām [saplosīšanai] pametami" (lat. non inique bestiis obiciuntur) (D 47.14.1.3.) [5, 838].

Ja minēto paaugstinātās bīstamības apstākḷu nebija, mājlopu zagḷus / aizdzinējus mēdza sodìt, piespriežot tiem dažādus darbus: “.. citādi gan uz [piespiedu] darbu .. notiesāti tiek” (lat. alioquin et in opus .. dantur) (D 47.14.1. pr.) [5, 837]. Šāda veida sodi varēja nozīmèt gan verdzību antīkajā derīgo izrakteņu ieguves industrijā - raktuvju sodu (lat. metalli peonam) -, gan kādus citus spaidu darbus (lat. operis) (D 47.14.1.3.) [5, 838]. Sodi varēja būt gan beztermiṇa, gan terminēti: “.. dažreiz [arī tikai] uz laiku notiesāti tiek” (lat. .. nonnumquam temporarium dantur) (D 47.14.1. pr.) [5, 837].

Tika pieḷautas atlaides attiecībā uz sabiedrības augstāko slāṇu pārstāvjiem - tie, kas bija nākuši no "godājamākas vietas" (lat. honestiore loco) Romas Impērijas sabiedriskajā hierarhijā bija sodāmi nevis ar iepriekšminētajiem sodiem, bet gan pazemināmi vai atceḷami / izslēdzami no kārtas (lat. aut relegandi .. aut movendi ordine). Minētā privilēgija tomēr neattiecās uz mājlopu zag̣̦iem / aizdzinējiem - bruṇotiem laupîtājiem, kas jebkurā gadījumā riskēja saṇemt nāvessodu - saplosīšanu arēnā (D 47.14.1.3.) [5, 838].

Par vainu pastiprinošu apstākli atzina mājlopu aizdzišanu no to turēšanai paredzētajām telpām: "Vinuu arī vairāk jāapvalda / jāsoda" (lat. eum quoque plenius coercendum), "kurš no stalılla nozadzis / aizdzinis pieradinātus liellopus" (lat. qui a stabulo abegit domitum pecus), "ne no meža, nedz no ganāmpulka" (lat. non a silva nec grege) (D 47.14.3.1.) [5, 838].

Par argumentu soda mīkstināšanai uzskatīja nolaupito dzīvnieku mazāku ekonomisko nozīmību. Cūku, kazu vai aitu aizvedējs varēja cerēt uz mazāk bargu sodu nekā tas, "kurš lielākus dzīvniekus aizved / nolaupa" (lat. qui maiora animalia abigunt) (D 47.14.1.2.) [5, 838].

Arī mājlopu zagḷu / aizdzinēju atbalstītāju sodīšanai tika piemērotas visai nopietnas sankcijas - šādu pārkāpēju slēpēji (lat. receptores abigeorum) riskēja ar iespējamu deportāciju un dzīves vietas izvēles ierobežojumiem. Slēpējiem draudēja izraidīšana un aizliegums uzturēties Itālijas teritorijā (lat. extra terram Italiam .. relegarentur). Minētā tiesību ierobežojuma terminš - uz desmit gadiem (lat. decem annis) (D 47.14.3.3.) [5, 838]. Tādējādi var secināt, ka sankcijas par mājlopu zagšanu / aizdzī̌̌anu bija loti bargas.

Salīdzinājumam, ja tika pastrādāta "parasta" zādzība (lat. furtum) ${ }^{9}$, tad iespējamo sankciju mehānisms tradicionāli izpaudās kā cietušā tiesības vērsties pret vainīgo tiesā

9 Atšḳirībā no abigeatus (lat.) - lopu zādzības/aizdzīšanas - ar zādzību (lat. furtum) saprata visādu veidu piesavināšanos un/vai izšḳērdēšanu. Par zādzības objektu neatzina nekustamu lietu - zemes gabalu utt. - piesavināšanu (D 47.2.25. pr.), bet atzina tiesību apdraudēšanu attiecībā uz visu, kas bija no zemes atrauts - piemēram, izraktiem kokiem, patvarīgi paṇemtiem akmen,iem, smiltìm, augsni, 
Allars Apsītis, Osvalds Joksts. Abigeatus - mājlopu zādzība jeb aizdzīšana -

kā noziedzīgs nodarījums pret īpašumu romiešu tiesībās

un pieprasìt kompensāciju - par furtum manifestum (lat.) jeb zādzību, kad zaglis piekserts, pastrādājot noziegumu, - četrkārtīgā, par furtum nec manifestum (lat.) jeb zādzību, kuru pastrādājot zaglis nav pieḳerts, - divkāršā nozagtās lietas vērtības jeb nodarītā zaudējuma apmērā (I 4.1.5.) [6, 43].

Tāpat cietušais varēja zagto mantu no jebkura caur tiesu atprasīt, turklāt nebija svarīgi, vai manta atradās pie paša zagḷa, zag̣̣a mantinieka vai kāda cita prettiesiska valdìtāja (I 4.6.19.) [6, 48]. Turklāt tika apgrūtināta nozagtās lietas izmantošana civiltiesiskajā apgrozībā. Tā, piemēram, sabiedrības līguma (lat. societas) slēgšanas un no tā izrietošās kapitālu apvienošanas gadỉjumā nebija aṭ̣auts prettiesiski iegūtas mantas ieguldījums - "ienākumi no zādzības vai jebkāda cita likumpārkāpuma nebūtu ieguldāmi sabiedrības kopējā mantā, jo sabiedrība attiecībā uz noziegumu ir zemiska un apkaunojoša" (D 17.2.53.) [1, 12]. Atškirīibā no vēl viena līdzīga pārkāpuma - laupīšanas (lat. rapina) -, kas nozīmēja svešas mantas atñemšanu - piesavināšanos ar spēka palīdzību ("nekaunīga zādzība"; sk. I. 4.2. tit.) -, zādzība (lat. furtum) nesaturēja vardarbības elementu $[1,7]$.

Savukārt apskatītā abigeatus - mājlopu zādzība / aizdzīšana - šādu vardarbības elementu bieži vien saturēja, ar ko cita starpā tika pamatoti bargie un nežēlīgie sodi: ".. Bet tāpēc, ka lielākoties [pie] mājlopu zādzības / aizdzīšanas arī ieroči lietoti ir" (lat. sed quia plerumque abigei et ferro utuntur), "ja [vainīgie] piekerti / notverti tiks" (lat. si deprehendentur), "[tad] tāpēc arī smagāk sodìt viṇu pastrādāto parasts" (lat. ideo graviter et puniri eorum admissum solet) (D 47.14.2.) [5, 838].

Vēl jāpiemin kāda procesuāla nianse: sūdzības par abigeatus - mājlopu zādzību / aizdzī̌sanu - varēja tikt iesniegtas ne vien rakstveidā, bet arī mutiski: "Dzīvnieka zādzības / aizdzīšanas apsūdzība ne tikai vienīgi ar ierakstiem" (lat. abacti animalis accusatio non solum cum inscriptionibus), "bet pat bez šo [formalitāšu] ievērošanas iesniegta tiek" (lat. sed etiam sine ea observatione proponitur) (C 9.37.1.) [4, 387].

Saistībā ar abigeatus - mājlopu zādzību / aizdzī̌̌anu - romiešu tiesību normas cenšas regulēt arī loti specifisku, tomēr praktiskajā dzīvē iespējamu situāciju. Proti, kāds ir nozadzis / aizdzinis (lat. abegit) cita valdījumā (faktiskā kontrolē ar nodomu paturēt) bijušus mājlopus, kurus uzskata par saviem. Respektīvi, pastāv strīds par īpašuma tiesībām uz minētajiem dzìvniekiem un viena no iesaistītajām pusēm ir mēǵinājusi šo piederības strīdu (lat. proprietate controversiam) atrisināt ne pārāk likumīgā - patvarīgā - ceḷā.

dažādiem dabiskajiem augḷiem utt. (D 47.2.25.2.). Tehniski zādzība varēja izpausties, piemēram, kā kāda mājā esošo lietu neatlauta paṇemšana un prom aiznešana, dārzkopības vai vīnkopības kultūraugu ražas neatḷauta novākšana un piesavināšana (I 4.1.3.), verga (D 47.2.14.5.) vai atsevišķa jūga lopa nozagšana (D 47.2.14.15.), audumu (D 47.2.19.4.) vai apgēerba gabalu (D 47.2.14.15.) zādzība, sadzīves priekšmetu - dzeramkausu (D 47.2.21.4.) vai citu trauku (D 47.2.19.1.) - neatḷauta paṇemšana, dārgmetālu (D 47.2.19.2.) vai naudas - monētu (D 47.2.19.3.) - nozagšana, pārtikas produktu - vīna - zādzība no noliktavas (D 47.2.21.6.), celtniecības materiālu - baḷ,ku - patvarīga aiznešana un piesavināšana (D 47.2.21.9.), citam adresētas vēstules pārtveršana (D 47.2.14.17.), grāmatvedïbas vai citu dokumentu nozagšana (D 47.2.27. pr., 1-3) u. c. [1, 8]. 
Allars Apsītis, Osvalds Joksts. Abigeatus - mājlopu zādzība jeb aizdzīšana -

kā noziedzīgs nodarījums pret ìpašumu romiešu tiesībās

Šādā gadījumā pienācās rīkoties šādi: ja nodarījuma pastrādātājs spēja pierādīt, ka viṇam nav bijis nolūka veikt pretlikumīgu mājlopu nolaupī̌anu, viṇš atradies pārliecībā, ka lopi ir viṇa un vin̦š rīkojas likumīgi: “.. ja neizskatās, [ka] mājlopu zādzība / aizdzī̌sana iecerēta ir" (lat. si non color abigeatus quaesitus est), "bet [apsūdzētais] patiesi domā, [ka] no savām tiesībām izrietoši vadījies" (lat. sed vere putavit sua iustis rationibus ductus), tad pastrādātājs par abigeatus - mājlopu zādzību / aizdzī̌sanu - nebija vajājams, savukārt konfliktā iesaistītajām pusēm piekrita iespēja pierādīt savu taisnību tiesā: “.. uz pārbaudi civilu / civiltiesisku atlaižams ir" (lat. ad examinationem civilem remittendus est) (D 47.14.1.4.) [5, 838].

Jāpiezīmē, ka minētajā normā ietvertās romiešu juridiskās doktrīnas idejas ir atstājušas l̦oti nozīmīgu ietekmi uz mūsdienu krimināltiesību koncepciju. Respektīvi, šeit rodami pirmsākumi domai par t. s. subjektīvo pusi - personas, kas izdarijusi nodarïjumu, psihisko attieksmi pret nodarïjumu, "pret pašas izdarīto darbību vai bezdarbïbu un nodarījuma kaitīgajām sekām" [3, 10] - kā vienu no t. s. noziedzīga nodarījuma sastāva obligātajiem elementiem, bez kura pierādāmas esamības nav iespējama saukšana pie kriminālatbildības. ${ }^{10}$ Tādēl romiešiem varam pateikties par ideju attiecībā uz subjektīvās puses nozīmi noziedzīga nodarījuma kvalificēšanā. ${ }^{11}$

\section{Secinājumi}

Abigeatus (lat.) - mājlopu zādzība jeb aizdzīšana - tika uzskatīta par bīstamāku un smagāku pārkāpumu nekā parasta zādzība (lat. furtum) un smagāk sodīta. Noziedzīgā nodarïjuma subjekts - mājlopu zaglis / aizdzinējs (lat. abigeus, arī abactor) - kvalificējas kā pārkāpējs profesionālis, kas mājlopu zagšanas / aizdzišanas nodarbi piekopj gluži kā mākslu vai arodu (D 47.14.1.1.).

Lai pastrādātāju atzītu par mājlopu zagli, pietika ar viena zirga vai liellopa aizvešanu. Attiecībā uz ekonomiski mazāk nozīmīgiem mājdzīvniekiem viss bija atkarīgs no aizdzìto dzīvnieku skaita. Tā desmit (vai vairāk) aitas uzskatìja par ganāmpulku un

${ }^{10}$ Arī runājot par romiešu zādzības (lat. furtum) koncepciju, jānorāda, ka tā nepārprotami paredzēja: pastrādātāja apziṇa un nodoms ir viens no zādzību raksturojošajiem pamatelementiem - ".. quia furtum sine affectu furandi non commitur" (lat.) - “.. jo nav zādzības bez nolūka nozagt” (I 4.1.7.) $[1,11]$.

11 Jānorāda, ka romiešu tiesību avotos ir stingri proponēta arī mūsdienu krimināltiesībās pārṇemtā ideja par noziedzīga nodarījuma kvalifikācijas neiespējamību bez sastāva objektīvo pazīmju esamības. Respektīvi, romiešu izpratnē “.. vienīgi nodoms zādzību pastrādāt [vēl] nav zādzība” - “.. sola cogitatio furti faciendi non facit furem” (lat.) (D 47.2.1.1.). Ir nepieciešams, lai būtu notikušas arī attiecīgas darbības - jānotiek lietas faktiskai sagrābšanai (D 47.2.53.19.). Arī pats termins furtum esot cēlies no vārdiem, kas apzīmē darbību veikšanu - vārdiem "fraus" vai "ferre", kuri nozīmējot "aiznest līdzi”, vai no grieḳu vārda "\{phor\}", "zaglis", kas pats cēlies no "\{pherein\}" - "aiznest līdzi”, "aiznest prom". Romiešu juristi vārda furtum izcelsmi saista arī ar vārdu "furvum", kas nozīmējot "melns", jo zādzība tiekot pastrādāta slepeni, aizsegā un parasti pa nakti (I 4.1.2.; D 47.2.1. pr.) $[1,11]$. 
to nolaupitājus atzina par mājlopu zādzību pastrādājušiem. Ja aizdzìto aitu skaits bija mazāks, vainīgie par mājlopu aizdzinējiem nekvalificējās, bet bija pastrādājuši parastu zādzību. Cūku zādzības gadījumā šāds skaitlis bija četras vai vairākas nolaupītas cūkas (D 47.14.3. pr.).

Recidìva - atkārtoti pastrādāta nodarījuma gadījumā - mājlopu zādzība jeb aizdzī̌̌ana tika kvalificēta vienmēr, lai kāds būtu aizvesto dzīvnieku veids vai skaits (D 47.14.3.2.). Par mājlopu zādzību jeb aizdzīšanu neatzina bez uzraudzības atstātu vai noklīdušu mājdzīvnieku nelikumīgu piesavināšanu (D 47.14.1.1.). Tā kā mājlopu zādzība / aizdzīšana bija smagāks nelikumīgs nodarījums nekā parasta zādzība (lat. furtum), arī piemērojamie sodi bija bargāki.

Teritorijās, kur mājlopu aizdzišanas netikums bija īpaši izplatīts, mājlopu aizdzinējiem piemēroja nāvessodu (D 47.14.1. pr., D 47.14.1.3.). Tāpat nāvessods - nodošana plēsīgiem zvēriem saplosǐšanai - draudēja gadījumos, kad mājlopi tika nolaupīti, izmantojot bruṇotu vardarbību (D 47.14.1.3.). Ja šādu paaugstinātas bīstamības apstākḷu nebija, mājlopu zagḷus mēdza sodīt, piespriežot piespiedu darbus (D 47.14.1. pr.) - gan faktisku verdzību derīgo izrakteņu raktuvēs, gan citus spaidu darbus (D 47.14.1.3.). Sodi varēja būt gan beztermiņa, gan terminēti (D 47.14.1. pr.).

Tika piel̦autas atlaides attiecībā uz sabiedrības augstāko slāṇu pārstāvjiem, kas bija sodāmi ar pazemināšanu pakāpē vai izslēgšanu no kārtas. Minētā privilēǵija neattiecās uz mājlopu zagliem bruṇotiem laupîtāiem, kas jebkurā gadījumā bija nododami plēsīgiem zvēriem saplosǐšanai (D 47.14.1.3.).

Par vainu pastiprinošu apstākli atzina mājlopu aizdzišanu no turēšanai paredzētām telpām (D 47.14.3.1.). Savukārt par argumentu soda mīkstināšanai uzskatīja nolaupīto dzīvnieku mazāku ekonomisko nozīmību. Cūku, kazu vai aitu aizvedējs varēja cerēt uz mazāk bargu sodu nekā tas, kurš lielākus dzīvniekus nolaupa (D 47.14.1.2.). Arī mājlopu zagḷu atbalstītāju sodīšanai tika piemērotas nopietnas sankcijas - pārkāpēju slēpēji riskēja ar deportāciju un dzīves vietas izvēles ierobežojumiem. Termiñš - desmit gadu (D 47.14.3.3.).

Salīdzinājumam - ja tika pastrādāta "parasta" zādzība (lat. furtum), sankciju mehānisms izpaudās kā cietušā tiesības vērsties pret vainīgo tiesā un pieprasìt kompensāciju (I 4.1.5.). Tāpat cietušais varēja zagto mantu no jebkura caur tiesu atprasìt - nebija svarīgi, vai manta atradās pie paša zag̣̦a, zag̣̣a mantinieka vai kāda cita prettiesiska valdītāja (I 4.6.19.). Turklāt tika apgrūtināta nozagtās lietas izmantošana civiltiesiskajā apgrozībā (D 17.2.53.). Atškirīibā no līdzīga pārkāpuma - laupiěanas (lat. rapina), kas nozīmēja svešas mantas atņemšanu - piesavināšanos ar spēka palīdzību (sk. I. 4.2. tit.), - zādzība nesaturēja vardarbības elementu. Savukārt abigeatus - mājlopu zādzība / aizdzī̌̌ana vardarbības elementu bieži vien saturēja, ar ko cita starpā tika pamatoti bargie un nežèlīgie sodi (D 47.14.2.).

Procesuālā ziṇā sūdzības par mājlopu zādzību / aizdzišanu varēja tikt iesniegtas ne vien rakstveidā, bet arī mutiski (C 9.37.1.). Ja nodarījuma pastrādātājs spēja pierādīt, ka viṇam nav bijis nolūka veikt pretlikumīgu mājlopu nolaupīšanu, bet tas atradies pārliecībā, 
ka mājlopi ir viṇa un viņš rīkojas likumīgi, tad pastrādātājs par mājlopu zādzību / aizdzī̌̌anu nebija vajājams un konfliktā iesaistītajām pusēm piekrita iespēja pierādīt savu taisnību tiesā (D 47.14.1.4.). Minētajā normā ietvertās romiešu juridiskās doktrīnas idejas atstājušas nozīmīgu ietekmi uz mūsdienu krimināltiesību koncepciju. Šeit rodami pirmsākumi domai par t. s. subjektīvo pusi - personas, kas izdarïjusi nodarijumu, psihisko attieksmi pret nodarījumu - kā vienu no noziedzīga nodarỉjuma sastāva obligātajiem elementiem.

\section{Abigeatus - Cattle Stealing or Rustling - as Criminal Offence Against Property in Roman Law}

\section{Abstract}

The article deals with the results of research performed on the primary sources of the Roman Law regarding offences against property contemporaneity criminalised in the Criminal Law (Sections 175. Theft, 176. Robbery, 179. Misappropriation) of modernday Latvia. It describes and analyses the Roman Law legal regulation regarding abigeatus the offence of cattle stealing or "rustling" which was considered as a more dangerous and serious offense than ordinary theft (furtum) and therefore more severely punishable. According to the information in the possession of the authors, Latvian researchers have not yet in particular studied the current theme, and the publications in the Latvian language have not been detected yet. Accordingly, the current article could provide certain contributions to the development of the national field of law, especially regarding the impact of Roman legal principles on the development of modern legal institutes incorporated in the law of the Republic of Latvia.

Keywords: abigeatus, cattle stealing, rustling, Roman Law.

\section{Avoti un literatūra}

1. Apsītis, A., un Joksts, O. (2013). Noziedzīgs nodarījums zādzība (furtum) romiešu tiesību kontekstā. Administratìvā un Kriminālā Justīcija. 1(62), 7, 8, 11, 12.

2. Berger, A. (1953, 1991). Encyclopedic Dictionary of Roman Law. Philadelphia: The American Philosophical Society, 338.

3. Krastiņš, U. (2000). Noziedzīgs nodarījums. Rīga: Tiesu namu aǵentūra, 10.

4. Krueger, P. (1906). Corpus Iuris Civilis, Editio Stereotypia Octava, Volumen Secundum, Codex Iustinianus, Recognovit Paulus Krueger. Berlīne: Weidmannos, 387. Iegūts no: http://fama2.us.es/ fde/ocr/2007/corpusIurisCivilisCodexIustinianus.pdf, 417 [sk. 06.01.2021.].

5. Krueger, P., \& Mommsen, T. (1928). Iustiniani Digesta. Corpus Iuris Civilis, Editio Stereotypia Quinta Decima, Volumen Primum, Institutiones, Recognovit Paulus Krueger, Digesta, Recognovit 
Allars Apsītis, Osvalds Joksts. Abigeatus - mājlopu zādzība jeb aizdzīšana -

kā noziedzīgs nodarījums pret ìpašumu romiešu tiesībās

Theodorus Mommsen, Retractavit Paulus Krueger. Berlīne: Weidmannos, 837, 838. Iegūts no: http://fama2.us.es/fde/ocr/2006/corpusIurisCivilisT1InstitutionesDigesta.pdf, 920, 921 [sk. 06.01.2021.].

6. Krueger, P., \& Mommsen, T. (1928). Iustiniani Institutiones. Corpus Iuris Civilis, Editio Stereotypia Quinta Decima, Volumen Primum, Institutiones, Recognovit Paulus Krueger, Digesta, Recognovit Theodorus Mommsen, Retractavit Paulus Krueger. Berlīne: Weidmannos, 43, 48. Iegūts no: http://fama2.us.es/fde/ocr/2006/corpusIurisCivilisT1InstitutionesDigesta.pdf, 66, 71. [sk. 06.01.2021.].

7. Latvijas Republika. 08.07.1998. Krimināllikums: Latvijas Republikas likums. Latvijas Vēstnesis. 199/200. Iegūts no: https://likumi.lv/ta/id/88966-kriminallikums [sk. 06.01.2021.]. 